\title{
PERTANGGUNGJAWABAN PIDANA OLEH KORPORASI DALAM TINDAKAN PELANGGARAN HAM DI INDONESIA
}

\author{
Oleh: Levina Yustitianingtyas \\ Fakultas Hukum Universitas Hang Tuah \\ E-mail: Firman.yusticia86@gmail.com
}

\begin{abstract}
This law research focuses on the issue of how the corporate criminal liability for human rights violations in Indonesia is. The method used is normative juridical. This research concluded that first, the corporate criminal liability for human rights violations is necessary, not only because sometimes countries are not prepared and do not have power to convict the corporation by reason of fear to bear the negative economic consequences, but also because the corporation is proved able to commit human rights violations that cause remarkable and prolonged negative effects, second, the protection of human rights in Indonesia has not maximally implemented yet until now because the recognition of the corporation as the subject offense in violations of human rights will have implications for the formulation of participation in criminal acts, limitation of liability, and other forms of criminal sanctions.
\end{abstract}

Keywords: Corporation, Human Rights, Criminal Liability

\section{A. LATAR BELAKANG}

Pada kehidupan manusia yang serba modern sekarang ini, korporasi memiliki peranan yang sangat penting terhadap pertumbuhan ekonomi suatu negara, seperti meningkatkan penerimaan pajak dan standar hidup masyarakat, menciptakan lapa-ngan pekerjaan, serta berkontribusi positif terhadap pertumbuhan suatu negara. Bah-kan, dalam beberapa aspek, peranan korporasi melebihi peranan dan pengaruh sua-tu negara. Dari tahun ke tahun, kuantitas korporasi terutama korporasi multinasional (Multi National Corporation) mengalami peningkatan yang luar biasa.

Namun demikian, peranan penting dan positif korporasi terhadap pertumbuhan ekonomi suatu negara seringkali diikuti oleh pelanggaran-pelanggaran yang mengarah pada hukum pidana. Tidak jarang korporasi melakukan unfair business (usaha tidak sehat) yang tidak hanya merugikan suatu negara dan konsumen, tapi juga dapat dikategorikan se-bagai tindak pidana. Ketika korporasi melakukan tindak pidana, maka ia dapat dipertang-gungjawabkan atas tindak pidana yang dilakukan baik ditujukan kepada pengurusnya mau-pun ditujukan langsung kepada korporasi. Pengakuan korporasi sebagai subjek delik dalam hukum pidana bukan merupakan hal baru dan tidak menimbulkan persoalan hukum yang berarti. Permasalahan baru 
muncul manakala korporasi melakukan tindak pidana yang di-kategorikan sebagai pelanggaran Hak Asasi Manusia (HAM) seperti kejahatan terhadap kemanusiaan, genosida, pelanggaran atas kebebasan individu, kejahatan perang dan lain sebagainya. Hal ini karena baik Statuta Roma maupun Undang-Undang No. 26 Tahun 2000 tentang Pengadilan HAM tidak mengakui korporasi sebagai subjek delik. Kedua instrumen hukum tersebut hanya mengenal pertanggungjawaban pidana individu (individual criminal responsibility) bukan pertanggungjawaban pidana korporasi (cor-porate criminal respon-sibility).

HAM sendiri adalah merupakan suatu konsep moral dalam kehidupan berma-syarakat dan bernegara dan bukanlah suatu konsep yang lahir seketika dan bersifat menyeluruh. HAM lahir secara bertahap dan seiring waktu tertentu dalam dinamika sejarah manusia. Sebagai konsep moral HAM yang dibangun dan dikembangkan se-cara empirik dalam kehidupan dan kepentingan kelompok sosial di dalam kehidupan masyarakat bernegara.

Gagasan tentang perlindungan HAM yang fundamental untuk pertama kali dike-mukakan oleh sejumlah karya tulis di belahan dunia. Gagasan tersebut bersumber pada filsaat Barat dan cara berpikir orang Barat, diantaranya yang dikemukakan oleh Marxisme (Peter R, Beaher, 1998: 15). Kehendak untuk melindungi hak individu terdapat dalam tradi-si dunia barat. Dalam tradisi ini HAM khususnya berkaitan dengan individu yang tidak bo-leh dilaggar oleh individu lainnya, oleh kelompok bahkan oleh negara atau penguasa. Di sini terdapat perbedaan yang sangat signifikan dengan pedekatan-pedekatan dominan non-Barat. Donnelly melihat tekanan pada in-dividu sebagai salah satu perbedaan peting antara pandangan moderen Barat dan pandangan non Barat mengenai martabat manusia. Ia berpendapat bahwa perlindu-ngan individu dari tuntutan masyarakat pada dasarnya bukan merupakan bagian dari pemikiran non-Barat tradisional (Jack, Donnelly, 1989: 57).

Di Indonesia rezim Orde Baru yang berkuasa selama 32 tahun dicatat telah banyak melakukan pelanggaran HAM karena perilaku negara khususnya aparat keamanan. Komisi Nasional HAM (Komnas HAM) menyebutkan pemerintah perlu menuntaskan segala bentuk pelanggaran HAM yang pernah terjadi sebagai akibat struk-tur kekuasaan Orde Baru yang otoriter. Kemudian pasca Orde Baru, banyak terjadi pelanggaran HAM yang berbentu aksi kekerasan massa, konflik antaretnis, dan pem-bumihangusan di Timor-Timur pasca jajak pendapat yang menelan korban jiwa cu-kup banyak.

Pelanggaran HAM pada masa Orde Baru juga disebabkan oleh sistem politik yang tidak demokratis yang kemudian membuka peluang bagi peguasa, termasuk para penegak hukum, untuk melakukan pelaggaran HAM melalui celah-celah konstitusi dengan mem-buat kebijakan-kebijakan pemerintah yang riskan terhadap pelang-garan HAM seperti di Aceh. Di lain pihak, terjadinya pelaggaran HAM juga disebabkan oleh kesadaran hukum masyarakat yang masih rendah dan suka main hakim sendiri (eigenrichtig). Hal ini dilatarbelakangi oleh rasa tidak puas masyarakat terhadap ke-bijakan pemerintah, perlakuan yang dikriminatif oleh 
aparat dalam melakukan pene-gakan. Oleh karena itu, dalam melakukan perlindungan HAM ada tiga faktor peting yang perlu diperhatikan yaitu para penguasa, termasuk aparat penegak hukum, harus melaksanakan tugas dan wewenang sebagaimana mestinya, dibentuknya peraturan-peraturan yag mengatur HAM dan adanya kesadaran masyarakat.

Pelanggaran HAM terjadi karena adanya ketimpangan antara nilai-nilai yag diharapkan dengan nilai-nilai kapabilitas yang diperlukan untuk meraih suatu harapan. Kekecewaan warga masyarakat terhadap deprivasi dan perlakuan yang tidak adil merupakan motivasi utama munculnya pelaggaran HAM. Pada dasarnya, masalah HAM itu terjadi seiring denga perubahan-perubahan pada diri masyarakat dan tidak dapat dipisahkan dari realitas sosial yang terus berkembang. Dalam perkembangannya, hal tersebut akan selalu bersing-gungan dengan persoalan politik, namun sebagai bagian dari realitas sosial, HAM dalam kehidupan bernegara harus memberi-kan jaminan kepastian hukum yang melandasi realita perlindungan dengan prinsip moralitas dan keadilan.

Berdasarkan latar belakang permasalahan tersebut diatas, dalam penelitian hukum ini maka dirumuskan permasalahan sebagai berikut:

Bagaimanakah pertanggungjawaban korporasi dalam pelanggaran HAM yang terjadi di Indonesia?

\section{B. METODE PENELITIAN}

Penelitian ini merupakan penelitian hukum normatif yang mengkaji kaidah perundang-undangan (Soetandyo Wigjnosoebroto, 2002) dan perkara pelanggaran HAM yang dilakukan oleh korporasi. Bahan hukum yang digunakan adalah bahan hukum primer, bahan hukum sekunder, dan bahan tersier. Sedangkan pendekatan yang digunakan adalah pendekatan perundang-undangan (statute approach), dan pendekatan kasus (case approach) (Peter Mahmud Marzuki, 2002). Bahan hukum di-kumpulkan dengan dua cara, yaitu studi dokumen dan studi literatur terkait dengan keberadaan korporasi dalam pelanggaran HAM yang terjadi di Indonesia.

\section{PEMBAHASAN}

\section{Pengertian Korporasi dan Pertanggungjawaban Pidana}

Kata korporasi berasal dari kata 'corporation' dalam bahasa latin yang berarti hasil dari pekerjaan yang membadankan, dengan kata lain badan disini diartikan sebagai orang. Menurut Rudi Prasetyo dalam buku Muladi, yang menyatakan bahwa korporasi merupakan sebutan yang lazim digunakan di kalangan pakar hukum pi-dana untuk menyebutkan apa yang biasa dalam hukum perdata, sebagai badan hu-kum atau yang dalam bahasa Belanda disebut sebagai rechtspersoon, atau yang dalam bahasa Inggris disebut sebagai legal entities atau corporation (Muladi, dkk, 1992: 12-15). 
Menurut Roeslan Saleh dalam buku Muladi pengertian pertanggung jawaban tidak termasuk hal perbuatan pidana. Perbuatan pidana hanya menunjuk pada perbuatan yang di-larang, apakah orang yang telah melakukan perbuatan itu kemudian juga dipidana ter-gantung pada soal apakah dia melakukan perbuatan itu memang mempunyai kesalahan atau tidak. Apabila orang yang melakukan perbuatan pidana itu memang mempunyai kesalahan, maka tentu akan menerima saksi pidana. Dipida-nanya seseorang tidaklah cukup jika orang itu telah melakukan perbuatan yang ber-tentangan dengan hukum atau bersifat melawan hukum. Untuk pemidanaan masih perlu adanya syarat, bahwa orang yang melkaukan perbuattan itu mempunyai kesa-lahan atau bersalah (subjective guilt), dengan kata lain orang terse-but harus dapat mempertanggungjawabkan perbuatannya (Muladi, dkk, 1992: 12-15).

Orang yang telah melakukan perbuatan pidana kemudian juga dijatuhi pidana sebagaimana telah diancamkan, ini tergantrung dari persoalan apakah dalam melaku-kan perbuatan ini dia mempunyai kesalahan, karena ada asas dalam pertanggung-jawaban pidana ialah tidak dapat dipidana jika tidak ada kesalahan atau tiada pidana tanpa kesalahan (Gen straf zonder schuld; Actus non facit reum nisi mens sir rea) (Moelyatno, 1993: 158).

Keberadaan suatua badan hukum atau badan usaha yang menyandang istilah korporasi diterima dan diakui sebagai subyek hukum yang dapat melakukan tindak pidana serta dapat pula dipertanggungjawabkan (Hamzah Hatrik, 1996: 30). Dikaji dari aspek historis, pengakuan korporasi sebagai subjek delik dalam hukum pidana sudah berlangsung se-jak 1635 ketika sistem hukum Inggris mengakui bahwa kor-porasi dapat bertanggungjawab secara pidana atas tindak pidana ringan (Andrew Weissmann dan David Newman, 2007: 419). Amerika baru mengakui eksistensinya pada 1909 melalui putusan pengadilan, setelah itu, Belanda, Italia, Perancis, Kanada, Australia, Swiss, dan beberapa negara Eropa mengikuti trend tersebut, termasuk Indonesia (Hamzah Hatrik, 1996: 30).

Pertanggungjawaban korporasi dalam hukum pidana muncul tidak melalui penelitian yang mendalam para ahli, tapi sebagai akibat dari kecenderungan dari formalisme hukum (legal formalism). Doktrin pertanggungjawaban pidana korporasi telah berkembang melalui peran pengadilan tanpa adanya teori yang membenarkan-nya. Hakim di dalam sistem common law melakukan suatu analogi atas subjek hukum manusia, sehingga korporasi juga memiliki identitas hukum dan penguasaan kekaya-an dari pengurus yang menciptakannya (Andrew Weissmann dan David Newman, 2007: 418-419).

Para hakim yang pada waktu itu tidak memiliki banyak teori untuk membebankan tindakan para agen kepada korporasi, berusaha dengan suatu pertanyaan apakah suatu korporasi, dengan entitas hukum tanpa memiliki bentuk psikis yang jelas, dapat juga dipersyaratkan memiliki tindakan psikologis untuk adanya suatu penuntutan sebagaimana hal-nya kejahatan-kejahatan lain yang mensyaratkan adanya hal itu (Yedidia Z. Stern, 1987: 125). Berdasarkan pemikiran ini, akhirnya "disepa-kati" bahwa korporasi juga dianggap sebagai subjek hukum yang 
bertanggung jawab hanya pada kejahatan-kejahatan ringan. Kon-sep ini bertahan hingga akhir abad ke-19 (Yedidia Z. Stern, 1987: 125).

Baru kemudian, ahli sarjana hukum pidana mencari dasar pembenar perlunya korporasi dipertanggungjawabkan dalam hukum pidana. Pertama, korporasi meru-pakan aktor utama dalam perekonomian dunia, sehingga kehadiran hukum pidana dianggap sebagai metode yang paling efektif untuk mempengaruhi tindakan-tindakan aktor rasional korporasi (Pamela H. Bucy, 2007: 1288). Kedua, keuntungan yang di-peroleh korporasi dan kerugian yang diderita masyarakat dapat demikian besarnya, sehingga tidak akan mungkin seimbang bilamana korporasi hanya dijatuhi sanksi ke-perdataan (Beth Stephens, 2002: 46; Dwidja Priyanto,2004: 27-28; Mahrus Ali, 2008). Tindakan korporasi melalui agen-agennya pada satu sisi seringkali menimbulkan ke-rugian yang sangat besar di masyarakat, sehingga kehadiran sanksi pidana diharap-kan mampu mencegahnya dari mengulangi tindakannya itu (Geraldine Szott Moohr, 2002: 27).

Biasanya, pertanggungjawaban korporasi didasarkan pada doktrin responsdeat superior, suatu doktrin yang menyatakan bahwa korporasi sendiri tidak bisa melakukan kesalahan. Hanya agen-agen yang bertindak untuk dan atas nama korporasi saja yang dapat melakukan kesalahan. Oleh karenanya, pertanggung jawaban korporasi merupakan suatu bentuk pertanggung jawaban atas tindakan orang lain/agen (vicarious liability), di mana ia bertanggung jawab atas kesalahan yang dilakukan oleh para agen. Doktrin ini diambil dari hu-kum perdata yang diterapkan pa-da hukum pidana. Vicarious liability biasanya berlaku dalam hukum perdata tentang perbuatan melawan hukum berdasarkan doktrin respondeat superior (Sutan Remy Sjahdeini, 2006: 84). Ada tiga syarat yang harus dipenuhi untuk adanya pertanggung jawaban korporasi, yaitu; agen melakukan suatu kejahatan; kejahatan yang dilakukan itu masih dalam ruang lingkup pekerjaannya; dan dilakukan dengan tujuan untuk menguntungkan korporasi (V.S. Khanna, 2000: 1242-1243).

Doktrin respondeat superior menghasilkan tiga model pertanggungjawaban pidana korporasi, yaitu direct corporate criminal liability, strict liability, dan vicarious liability. Dalam Direct corporate criminal liability (pertangungjawaban korporasi secara langsung), korporasi bisa melakukan sejumlah delik secara langsung melalui para agen yang sangat berhubungan erat dengan korporasi, bertindak untuk dan atau atas nama korporasi. Syarat adanya pertanggungjawaban pidana korporasi secara langsung adalah tindakan-tindakan para agen tersebut masih dalam ruang lingkup pekerjaan korporasi (Sue Titus Reid, 1995; Wayne R LaFave \& Austin W. Scott Jr, 1982: 228). Direct corporate criminal liability berhubungan erat dengan doktrin iden-tifikasi, yang menyatakan bahwa pada dasarnya mengakui bahwa tindakan dari agen tertentu dari korporasi, selama tindakan itu berkaitan dengan korporasi, dianggap se-bagai tindakan dari korporasi itu sendiri (Eric Colvin, 1995: 8-9).

Strict liability diartikan sebagai suatu perbuatan pidana dengan tidak mensya-ratkan adanya kesalahan pada diri pelaku terhadap satu atau lebih dari actus reus (Russel Heaton, 2006: 403). Strict liability ini merupakan 
pertanggungjawaban tanpa kesalahan (liability without fault). Dalam artian disini bahwa dalam perbuatan pidana yang bersifat strict liability hanya dibutuhkan dugaan atau pengetahuan dari pelaku (terdakwa), sudah cukup menuntut pertanggungjawaban pidana dari padanya. Jadi, tidak dipersoalkan adanya mens rea karena unsur pokok strict liability adalah actus reus (perbuatan) sehingga yang harus dibuktikan adalah actus reus (perbuatan), bu-kan mens rea (kesalahan) (Hanafi, 1997: 63-64).

Vicarious liability (pertanggungjawaban pengganti) diartikan sebagai pertanggung jawaban menurut hukum seseorang atas perbuatan salah yang dilakukan oleh orang lain (Sue Titus Reid, 1995: 53). Teori ini juga hanya dibatasi pada keadaan tertentu dimana majikan (korporasi) hanya bertangungjawab atas perbuatan salah pekerja yang masih dalam ruang lingkup pekerjaannya (C.M.V. Clarkson, 1998: 44). Rasionalitas penerapan teori ini adalah karena majikan (korporasi) memiliki kontrol dan kekuasaan atas mereka dan keuntungan yang mereka peroleh secara langsung dimiliki oleh majikan (korporasi) (C.M.V. Clarkson, 1998: 45).

Prinsip hubungan kerja dalam vicarious liability disebut dengan prinsip delgasi, yakni berkaitan dengan pemberian izin kepada seseorang untuk mengelola sua-tu usaha. Pemegang izin tidak menjalankan langsung usaha tersebut, akan tetapi ia memberikan kepercayaan (mendelegasikan) secara penuh kepada seorang manager untuk mengelola kor-porasi tersebut. Jika manager itu melakukan perbuatan mela-wan hukum, maka pemegang izin (pemberi delegasi) bertanggungjawab atas perbua-tan manager itu.

Ketika korporasi dinyatakan bertanggungjawaban secara pidana atas tindak pidana yang dilakukan, maka dikenal tiga sistem pertanggungjawaban korporasi; yai-tu, pengurus korporasi sebagai pembuat, penguruslah yang bertanggungjawab, kor-porasi sebagai pembuat, pengurus yang bertanggungjawab, dan korporasi sebagai pembuat dan yang bertanggungjawab (Mardjono Reksodiputro, 1989: 9).

Dalam konteks pelanggaran HAM yang berat, korporasi tidak diakui sebagai subjek delik. Baik Statuta Roma maupun UU pengadilan HAM hanya mengakui individu sebagai subjek hukum dalam kejahatan HAM yang berat. Ketika terjadi perkara pelanggaran HAM yang berat, maka Mahkamah Pidana Internasional (International Criminal Court) atau Pengadilan HAM hanya berwenang mengadili perkara tersebut bila pelakunya adalah individu, bukan korporasi atau negara. Sebab, Statuta Roma atau Pengadilan HAM hanya mengenal pertanggungjawaban pidana individu (individual criminal responsibility).

Walaupun Statuta Roma secara eksplisit hanya mengakui pertanggungjawaban pidana individu, yang menarik adalah ternyata beberapa negara mengakui eksis-tensi korporasi sebagai subjek delik dalam pelanggaran HAM yang berat dan mene-rapkannya dalam kasus-kasus yang melibatkan korporasi. Paling tidak terdapat em-pat alasan yang dikemukan dalam hubungan ini. Pertama, perluasan subjek delik yang meliputi korporasi multinasional akan berguna, karena kadangkala negara-negara tempat di mana korporasi melakukan pelanggaran HAM 
yang berat tidak bersedia atau tidak memiliki kekuatan untuk men-jatuhkan sanksi pidana kepada korporasi disebabkan adanya rasa takut negara tersebut akan menanggung konsekuensi ekono-mi yang bersifat negatif. Kedua, dewasa ini peranan korporasi multinasional untuk melakukan kejahatan-kejahatan bisnis dan lingkungan hidup dalam skala yang besar seringkali terjadi dan kadangkala menimbulkan efek negatif yang berkepanjangan dan luar biasa. Ketiga, tidak sedikit korporasi yang memiliki "kebiasaan" melakukan tindak pidana dengan memelihara budaya korporasi yang memungkinkan terjadinya perbuatan-perbuatan yang dilarang (Thomas Weigend, 2008: 929-933).

Artinya, korporasi "memaksa" agen-agen agar terbiasa melakukan tindak pidana termasuk pelanggaran HAM yang berat, dengan tujuan agar keuntungan finan-cial yang diperoleh dalam jumlah yang besar dengan risiko yang kecil. Keempat, da-lam beberapa kasus seringkali korporasi terlibat langsung dalam pelanggaran HAM yang berat yang serius dan sistemasik, seperti pembunuhan, penyiksaan, penangka-pan secara tidak sah, kerja paksa, bentuk-bentuk lain eksploitasi anak, pelanggaran HAM yang berat terhadap individu dalam situasi perang dan konflik, kerusakan yang sangat parah terhadap lingkungan hidup. Salah satu contoh dari kasus tersebut ada-lah yang dilakukan oleh Militer Myanmar (Andrew Clapham, 2008: 903; Gregory G.A. Tzeutschler, 1999: 409-422).

Dasar untuk memasukkan korporasi sebagai pihak yang dapat melakukan pelanggaran HAM yang berat adalah berdasarkan empat alasan tersebut diatas. Oleh karena itu, beberapa negara seperti Australia, Belanda, Kanada dan Inggris secara eksplisit menjadikan korporasi sebagai subjek delik dalam perundang-undangan pidana mereka terkait pelanggaran HAM yang berat. Negara-negara tersebut memperluas subjek delik dalam Statu-ta Roma yang tidak hanya pada manusia tapi juga pada korporasi dalam pelanggaran HAM yang berat.

Dalam perkembangan hukum pidana Indonesia, ada 3 (tiga) sistem pertanggung jawaban korporasi sebagai sebagai subyek tindak pidana yaitu (Soepadi, 2010: 14) :

a. Pengurus korporasi sebagai pembuat, maka penguruslah yang bertanggung jawab

Pada sistem ini kepada pengurus dibebankan kewajiban-kewajiban tertentu. Kewajiban yang dibebankan itu sebenarnya adalah merupakan kewajiaban dari korporasi. Pengurus yang tidak memenuhi kewajiban tersebut diancam pidana. Korporasi itu sendiri tidak dapat dipertanggungjawabkan terhadap suatu pe-langgaran, melainkan selalu pengurus yang melakukan delik tersebut dan karenanya penguruslah yang diancam pidana dan dipidana (Muladi, dkk, 1996: 68).

b. Korporasi sebagai pembuat, maka pengurus yang bertangungjawab Dalam sistem pertanggungjawaban kedua ini ditegaskan bahwa korporasi mungkin sebagai pembuat. Pengurus ditunjuk sebagai yang bertanggungjawab dan apa yang dilakukan oleh korporasi adalah apa yang dilakukan oleh alat perlengkapan korporasi tersebut menurut wewenang anggaran 
dasarnya. Tindak pidana yang dilakukan oleh korporasi adalah tindak pidana yang dilakukan orang tertentu sebagai pengurus dari badan hukum tersebut. Prinsip ini hanya berlaku untuk pelanggaran saja (Muladi, dkk, 1996: 70).

c. Korporasi sebagai pembuat dan yang bertanggungjawab

Dalam sistem pertanggungjawaban yang ketiga ini merupakan permulaan adanya tanggung jawab yang langsung dari korporasi. Dalam system ini dibuka kemungkinan menuntut korporasi dan meminta pertanggung jawabannya menurut hukum pidana, hal ini disebabkan pertama, karena dalam berbagai tindak pidana ekonomi dan fiscal keuntugan yang diperoleh korporasi atau kerugian yang diderita masyarakat dapat sedemikian besar sehingga tidak mungkin seimbang bilamana hanya dijatuhkan pada pengurus saja, tidak atau belum ada jaminan bahwa korporasi tidak akan mengulangi tindak pidana lagi. Dalam sistem pertanggungjawaban yang ketiga ini, telah terjadi pergeseran pandangan, bahwa korporasi dapat dipertanggungjawabkan sebagai pembuat tindak pidana, disamping persoon. Jadi penolakan pemidanaan korporasi berdasarkan doktrin universitas delinquere non potest sudah mengalami perubahan dengan menerima konsep pelaku fungsional (functioneel daaderschap). Seiring peranan korporasi yaitu memperoleh keuntungan yang besar seringkali kecenderungan korporasi melakukan pelanggaran hukum, oleh karena itulah maka pengaturan korporasi sebagai subyek tindak pidana dan pertanggungjawaban pidana korporasi diatur dalam beberapa peraturan perundang-undangan diluar KUHP (H. Soetiyono, 2003: 10).

\section{Negara dan HAM (Hak Asasi Manusia)}

Hak Asasi Manusia (HAM) sebagai suatu kosep yang berisikan moral dalam kehidupan bermasyarakat dan bernegara telah lama diperjuangkan secara individual maupun secara bersama-sama. Pada tahun 1215 para bangsawan telah berhasil m-emaksa raja Inggris untuk mengeluarkan Magna Charta Libertanum.

Piagam tersebut dikeluarkan oleh Raja Inggris sebagai piagam yang Fundmental sebagai konsep hak asasi manusia yang di dalamnya mengandung perlidungan hak asasi manusia yang berkaitan dengan larangan terhadap raja untuk melaku-kan penahanan, menghukum dan perampasan benda-benda secara sewenang-we-nang dan sekaligus melakukan perlindungan terhadap hak milik pribadi rakyat Ing-gris. Dengan demikian Piagam Magna Charta Libertanum ini merupakan prinsip-prin-sip moral dan sekaligus hukum yang diharapkan dapat mengendalikan kekuasaan raja di Inggris (Hadjon, Philipus, 2007: 23).

Piagam Magna Charta Libertanum kemudian dijadikan undang-undang Hak Asasi Manusia yang dibentuk sebagai perjuangan rakyat terhadap kekuasaan raja dan sekaligus sebagai pedoman dalam menegakkan hak asasi manusia dalam tatanan ke-hidupan berbangsa dan bernegara. 
Prinsip tatanan kehidupan berbangsa tersebut menurut Sri Hastuti (Hastuti, Sri Puspitasari, 2000: 46) dan bernegara yang paling fundamental meliputi tiga hal yakni:

a. Rakyat sebagai komponen utama negara

b. Negara sebagai institusi organisasi kekuasaan dan merupakan wadah ekspresi masyarakat dalam mengartikulasi kepentingannya.

c. Akses yang muncul dari dari hubungan antara masyarakat dan negara, dan akses tersebut berwujud pada masalah hak asasi dari individu yang merupakan bagian dari masyarakat dan negara.

Hukum HAM Internasional muncul sejak tahun 1945 ketika adanya implikasi dari bencana yang ditimbulkan oleh pengingkaran dari kaum Nazi terhadap hak asasi manusia. Pengalaman Perang Dunia I (PD I) dan Perang Dunia II (PD II) menjadi "stigma" bagi negara-negara yang terlibat perang maupun yang tidak kemudian men-jadi prinsip dasar dan tujuan utama dalam pembentukan Organisasi Perserikatan Bangsa-Bangsa (PBB). Bebera-pa instrumen yang berkaitan dengan HAM telah di-sahkan di ataranya sebagai berikut (Has-tuti, Sri Puspitasari, 2000: 46) :
a. Deklarasi Universal Hak Asasi Manusia dan Konvesi Genocida 1948.
b. Konvensi tentang Hak-Hak Politik kaum perempuan tahun 1952.
c. Peraturan standart minimum untuk perlakuan terhadap narapidana ta- hun 1957.
d. Konvensi tentang Penghapusan semua bentuk diskriminasi rasial tahun 1965.
e. Persetujuan internasional tentang Hak-Hak ekonomi sosial dan budaya pada tahun 1966.

Keterlibatan PBB yang serius dalam menangani persoalan-persoalan HAM selama ini ditunjukkan oleh upaya regional yang semakin meningkat pada kasuskasus HAM. Hal ini diwujudkan dengan melakukan konvesi Eropa tentang HAM, pembentukan komisi antar Amerika tentang HAM pada tahun 1960 dan diberlakukannya Konvensi Amerika ten-tang HAM pada tahun 1978. Dalam prakteknya, sumber-sumber yang paling peting dan berguna dari hukum HAM internasional adalah perjanjian-perjanjian internasional yang secara jelas dan lagsung meciptakan kewaji-ban-kewajiban internasional bagi para pihak. Tetapi perjanjian-perjanjian tersebut bersifat mengikat hanya apabila perjanjian itu berlaku dan berkenan dengan negara-negara yang secara tegas menjadi peserta dari perjanjian tersebut.

Negara merupakan sauatu organisasi yang di dalamnya mengandung kekuasaan. Dengan demikian negara merupakan elemnen yang sangat penting yang bertanggung jawab melakukan perlindungan terhadap HAM.

Negara dalam sistem hak asasi manusia tidak memiliki hak. Oleh karenanya negara hanya memiliki kewajiban atau tanggung jawab (obligation or respnsibility) untuk memenuhi hak-hak (yang dimiliki oleh individu atau kelompok) yang dijamin dalam instrumen-istrumen HAM. Apabila negara tidak memiliki keinginan untuk me-menihi kewajibannya itu, maka suatu negara dapat dikatakan telah melakukan 
pe-langgaran HAM atau hukum internasional. Apabila pelanggaran yang dilakukan oleh negara tersebut tidak dipertanggung jawabkan oleh negara, maka tanggung jawab itu akan diambil alih oleh masyarakat internasional. Hukum HAM internasional dengan dapat memberikan kemungkinan bagi individu suatu negara menghadapi sendiri negaranya di hadapan kelembagaan internasional.

Adanya instrumen HAM merupakan prestasi tersendiri dalam perjuangan pe-negakan hak asasi manusia, yakni tersedianya pedoman yang dapat digunakan dalam memberikan penilaian terhadap perilaku sebagian anggota masyarakat, khususnya perilaku dari mereka yang berkuasa kepada mereka yang tidak berkuasa. Namun, suatu permasalahan tampaknya sulit diselesaikan dalam memberikan perlindungan terhadap HAM adalah adanya perbedaan yang mencolok antara hasil yang telah di-capai dalam bentuk istrumen HAM dengan implementasinya.

Rendahnya implementasi instrumen HAM salah satunya ditujukkan oleh masih berlangsungnya praktek-praktek peyiksaan (tindak kekerasan) dan berbagai betuk perlilaku kejam terhadap manusia yang merupakan wujud dari pelanggaran HAM khususnya yang dilakukan oleh sesama warga negara sendiri, sekalipun telah ada konvensi anti penyiksaan yang berlaku sejak tahun 1948 (Antonio Casesse, 1997:16). Menurut konvensi ini yang dimaksud dengan penyiksaan atau hukuman lain yang kejam adalah sebagai berikut:

Segala tindakan yang dilakukan baik secara lagsung atau tidak langsung oleh aparatur pemerintah yang menimbulkan kesakitan atau penderitaan yang hebat baik jasmani maupun rohani secara terus-menerus pada diri seseorang dengan tujuan mengancam, memperloleh pengakuan, menghukum atau untuk melakukan diskriminasi.

Oleh karena itu menurut Peter Baeher, dkk (Baehr Peter, dkk, 1997: 706), semua negara harus mengambil langkah-langkah administratif, hukum yang efektif dan langkah-langkah lain utuk mencegah tindakan penyiksaan di wilayah manapun di bawah yurisdiksi. Di lain pihak, merebaknya "pengadilan massa" mencerminkan kesadaran hukum masya-rakat yang masih rendah karena mereka cenderung meyelesaikan masalah dengan melakukan eigenrichtig. Usaha memahami berkembangnya "pengadilan masa" (main hakim sendiri) kiranya harus di posisikan dalam konteks yang luas terjadinya kekerasan pada hukum itu sendiri yang tidak dapat memenuhi rasa keadilan masyarakat.

Pada sidang istimewa PBB yang diadakan bulan November 1998 kemudian di-tetapkan dalam Ketetapan MPR RI No. XVII/MPR/1998 tentang Hak Asasi Manusia yang berisikan (Baehr Peter, dkk, 1997: 706):

a. Bahwa manusia sebagai mahluk Tuhan Yang Maha Esa dianugerahi hak dasar yaitu hak asasi untuk dapat mengembangkan diri pribadi, peranan dan sum-bangan bagi kesejahteraan hidup manusia. 
b. Bahwa Pembukaan UUD 1945 telah mengamantkan pengakuan, penghormatan dan kehendak bagi pelaksanaan HAM dalam penyelenggaraan kehi-dupan bermasyarakat, berbangsa dan bernegara.

c. Bahwa bangsa Indonesia sebagai bagian masyarakat dunia patut menghormati HAM yang termaktub dalam Deklarasi universal HAM PBB serta berbagai instrumen internasional laninnya mengenai HAM. Adapun isi dari Piagam HAM PBB tersebut berisikan tentang:

a) Hak untuk hidup.

b) Hak berkeluarga dan melanjutkan keturunan.

c) Hak mengembangkan diri.

d) Hak keadilan.

e) Hak kemerdekaan.

f) Hak atas kebebebasan informasi.

g) Hak keamanan.

h) Hak kesejahteraan.

Berdasarkan Ketetapan MPR RI Nomor XVII/MPR/1998 pasal 4 bahwa, pelak-saaan, peyuluhan, pengkajian, pemantauan, penelitian dan mediasi tentang HAM di-lakukan oleh suatu Komisi Nasional Hak Asasi Manusia yang ditetapkan dengan un-dang-undang sesuai ketentuan Undang-Undang No. 39 tahun 1999 tentang Hak Asasi Manusia (LN RI Tahun 1999 No. 165). Dalam undang-undang ini terkandung hak un-tuk hidup, berkeluarga dan melajutkan keturunan, mengembangkan diri, memper-oleh keadilan, hak atas kebebasan pribadi, hak atas rasa aman, hak atas kesejah-teraan, hak turut serta dalam pemerintahan, hak wanita dan hak anak. Selain itu pe-merintah juga membentuk Undang-Undang No. 26 tahun 2000 tentang Pengadilan HAM termasuk di dalamya kejahatan Genosida dan kejahatan terhadap kemanusiaan yang tertuang dalam Undang-Undang No. 5 tahun 1998 (LN RI Tahun 1998 No. 164) tentang Konvesi Menentang penyiksaan dan peghukuman yang kejam.

Kemudian Undang-Undang Dasar 1945 juga mengatur tentang Hak Asasi Manusia yang pengaturannya ada pada Bab XA pasal 28 huruf a sampai dengan pasal 28 huruf j.

Selain itu beberapa konvesi yang telah diratifikasi oleh Pemerintah Indonesia antara lain:

a. Konvensi Jenewa tahun 1949 diratifikasi melalui UU No. 59 tahun 1958

b. Konvesi Hak Politik Kaum Wanita (Convention on the Political Rights of Wo-men) diratifikasi melalui UU No. 68 tahun 1958

c. Konvensi tentang Penghapusan segala bentuk diskriminasi terhadap wanita (Convention on the Elimination of All Forms of Discrimination Against Woman) diratifikasi melalui UU No. 7 tahun 1984.

d. Konvensi pelarangan, pengembangan, produksi dan penyimpanan senjata biologis dan beracun serta pemusnahannya (Convention on the Prohibition of the Development, Production and Stockpiling of 
Bacteriological (Biologi-cal) and Toxin Weapons and their Destruction) diratifikasi melalui Keputu-san Presiden Nomor 58 tahun 1991.

e. Konvensi Hak Anak (Convetion on the Right of the Children) diratifikasi melalui Keputusan Presiden No. 36 tahun 1990.

f. Konvesi Internasional terhadap Anti Aparheid dalam Olah Raga (International Convention Against Aparheid in Sports) diratifikasi melalui UU Nomor 48 tahun 1993.

g. Konvesi Organisasi Buruh Internasional Nomor 87 tahun 1998 tentang Kebebasan Berserikat dan Perlindungan Hak untuk Berorganisasi (ILO Convetion No. 87 Concerning Freedom of Association and Protection in the Right to Organize) diratifikasi melalui Keputusan Presiden No. 83 tahun 1998.

h. Konvensi menentang Penyiksaan dan perlakuan lain yang kejam, tidak manusiawi atau merendahkan martabat manusia (Convention Against Torture and Other Inhuman or Degrading Treatment or Punishment) dengan UU No. 5 tahun 1998.

i. Konvensi Internasional tentang Penghapusan Semua bentuk diskriminasi rasial (International Convantion on the Elimination of All Forms of Racial Discri-mination) diratifikasi melalui UU Nomor 29 tahun 1999.

\section{Pertanggungjawaban Korporasi dalam Pelanggaran HAM di Indonesia}

Pada Undang-undang Pengadilan HAM, Indonesia tidak mengakui korporasi sebagai subjek delik, sehingga kalaupun korporasi melakukan pelanggaran HAM yang berat, maka eksistensi undang-undang tersebut tidak dapat digunakan. Namun demi-kian, ketiadaan pengaturan korporasi sebagai subjek delik tidak kemudian menutup kemungkinan penerapan pertanggungjawaban pidana korporasi dalam pelanggaran HAM yang berat. Perlunya korporasi dipertanggungjawabkan secara pidana dalam pelanggaran HAM yang berat dalam sistem hukum pidana Indonesia setidaknya di-dasarkan pada dua alasan. Pertama, dampak negatif pelanggaran hukum oleh korpo-rasi begitu kompleks, tidak hanya aspek hukum saja tapi juga aspek ekonomi, sosial, politik, dan budaya. Kedua, korban pelanggaran HAM oleh korporasi tidak kalah se-dikit dibandingkan pelakunya manusia, bahkan dalam beberapa kasus terutama ter-kait dengan pencemaran lingkungan hidup, kondisi korban sangat mengenaskan. Ke-tiga, motif korporasi melakukan pelanggaran HAM lebih kompleks dibandingkan dengan motif individu. Hal ini karena umumnya, terdapat motif ekonomi yang selalu menyertai korporasi ketika melakukan pelanggaran HAM di samping motif yang lain (Soepadi, 2010: 21-22).

Korporasi diakui sebagai subjek delik dalam pelanggaran HAM, paling tidak terdapat tiga implikasi hukum yang perlu diperhatikan, yakni perumusan tindak pidana, pertanggungjawaban pidana, dan sanksi pidana. Hal ini karena prinsip-prinsip dasar terkait ketiga hal tersebut dalam sistem hukum pidana Indonesia masih menga-cu pada subjek delik berupa manusia, dalam arti perumusan tindak pidana, 
pertang-gungjawaban pidana, dan sangsi pidana lebih dominan mengarah pada subjek delik manusia.

Terkait perumusan tindak pidana yang dilakukan korporasi dalam pelanggaran HAM, ditolak pemikiran yang menyatakan bahwa korporasi tidak dapat membunuh, menculik, kerja paksa, melakukan pembersihan etnis, dan sebagainya yang se-lama ini umumnya dianggap hanya dapat dilakukan oleh manusia. Hal ini karena ter-bukti dalam dua kasus di atas, korporasi ternyata dalam melakukan tindakan pembu-nuhan walaupun tidak dilakukan secara langsung olehnya, tapi oleh pejabat senior atau perwakilannya. Selain itu, perumusan tindak pidana korporasi perlu diadakan rekonstruksi terutama terkait dengan delik penyertaan (turut serta).

Teori tentang turut serta pada umumnya menyatakan bahwa yang dimaksud turut serta (Mede pleger) adalah apabila perbuatan masing-masing peserta memuat semua anasir-anasir perbuatan pidana yang bersangkutan (Uttrect, 1960: 32-33). Moeljatno mengatakan bahwa mede pleger adalah setidak-tidaknya mereka itu semua melakukan unsur perbuatan pidana, dan ini tidak berarti bahwa masing-masing harus melakukan bahkan tentang apa yang dilakukan peserta/tak mungkin dilakukan karena hal ini tergantung pada masing-masing keadaan. Yang perlu ditekankan di sini adalah dalam mede pleger terjadi kerjasama yang erat antara mereka pada waktu melakukan perbuatan pidana (Moeljanto, 1983: 113).

Berdasarkan konsepsi teoritis tersebut, terdapat ciri tiga penting mede pleger yang membedakannya dengan bentuk penyertaan yang lain. Pertama, pelaksanaan perbuatan pi-dana melibatkan dua orang atau lebih. Kedua, semua yang terlibat, be-nar-benar melakukan kerja sama secara fisik (saling membantu) dalam pelaksanaan perbuatan pidana yang terjadi. Ketiga, terjadinya kerja sama fisik bukan karena kebe-tulan, tetapi memang telah merupakan kesepakatan yang telah direncanakan ber-sama sebelumnya ((Moeljanto, 1983: 113).

Bila konsep turut serta tersebut diterapkan kepada korporasi, syarat terjadinya kerjasama secara fisik sulit terpenuhi, karena umumnya korporasi tidak melakukan kejahatan secara langsung tapi melalui agen atau perwakilannya atau dilakukan langsung oleh partner kerjanya. Oleh karena itu, konsep turut serta dalam Pasal 55 KUHP perlu direkonstruksi bila diterapkan kepada korporasi, dalam artian agar korporasi terbukti melakukan delik penyertaan dalam pelanggaran HAM, maka ter-jadinya kerjasama secara fisik tidak mutlak di-perlukan, tapi cukup apabila antara korporasi dan orang lain atau entitas hukum yang lain telah ada pertemuan dan pe-rencanaan yang matang untuk terjadinya tindak pidana, tanpa harus mensyaratkan bahwa korporasi melalui agennya melakukan pelanggaran HAM secara langsung.

Dalam kaitan dengan siapa yang harus bertanggung jawab atas tindak pidana agen dari suatu korporasi, harus ada ketentuan limitatif yang berbeda dengan keten-tuan perundang-undangan pidana yang selama ini ada jika korporasi melakukan sua-tu tindak pidana. Dalam doktrin dikenal tiga pihak yang dapat bertanggung jawab, yakni korporasi sendiri, pengurus korporsi, atau korporasi dan 
pengurusnya. Untuk pelanggaran HAM yang berat yang dilakukan korporasi, hanya korporasi saja yang dapat dimintai pertanggungjawaban secara pidana.

Menurut V.S. Khanna mengatakan, paling tidak ada tiga alasan yang dapat dikemukakan. Pertama, para pengurus tidak memiliki banyak aset jika harus bertanggung jawab atas tindak pidana yang dilakukan oleh korporasi, jika sanksi pidana den-da dijatuhkan padanya. Oleh karena itu, masalah ini bisa diatasi dengan menyatakan bahwa satu-satunya pihak yang harus bertanggung jawab atas tindak pidana yang dilakukan oleh korporasi adalah korporasi itu sendiri. Kedua, hal itu akan memaksa korporasi untuk memonitor dan mencegah para agen melakukan tindak pidana, kare-na jika itu dilakukan, biaya yang harus ditanggung oleh korporasi sangat besar. Keti-ga, alasan untuk mempertanggungjawabkan korporasi adalah ia melakukan tindak pidana berdasarkan prinsip rasionalitas. Sementara, para agen melakukan tindak pi-dana tidak lain hanya sebagai "perantara" saja dari suatu korporasi (V.S. Khanna, 2000: 1243-1245).

Perubahan lain berkaitan dengan sanksi pidana, apabila dalam undang-undang pengadilan HAM ada tiga bentuk sanksi pidana yang dapat dijatuhkan kepada pelaku pelang-garan HAM, yakni pidana mati, pidana seumur hidup dan pidana penjara, maka harus ada penambahan bentuk sanksi di dalamnya. Menurut penulis, terdapat beberapa bentuk sanksi khusus bagi korporasi jika melakukan pelanggaran HAM, yaitu pidana denda, perampasan aset korporasi, dan perbaikan akibat tindak pidana, dan pemberian restitutsi kepada korban atau keluarganya. Bentuk sanksi pidana denda ini diterapkan mengingat korporasi itu me-miliki persona yang dapat diidentifikasi, di mana kehadirannya di dalam suatu masyarakat, sesungguhnya terpi-sah sama sekali dari pemilik, manager dan pekerja (Lawrence Fried-man, 2000: 847). Di samping itu, ketika melakukan suatu aktivitas, termasuk melakukan tindak pidana, korporasi berpikir (melalui agen) rasional yang menimbang antara untung dan rugi (Dan M. Khan, 1997: 349). Ketika suatu tindak pidana yang dilakukan ternyata men-datangkan keuntungan yang lebih besar dibandingkan dengan kerugian yang harus ditanggung, maka ia akan melakukan tindak pidana termasuk juga pelanggaran HAM yang berat.

Dalam kaitannya dengan teori pemidanaan, teori pencegahan (deterrence) le-bih tepat diterapkan kepada korporasi. Menurut teori ini adalah manusia, begitu juga korporasi, merupakan entitas rasional yang ketika akan melakukan tindak pidana akan menimbang antara keuntungan yang akan didapatkan dan kerugian yang akan ditanggung. Jika ternyata, keuntungan yang akan didapat lebih besar dari kerugian yang harus ditanggung, baik manusia maupun korporasi akan melakukan kejahatan. Konsekuensinya, sanksi pidana harus lebih berat dari seriusitas tindak pidana yang dilakukan (Gilbert Geis dan Joseph F. Dimento, 2002: 371-373). Karena dengan hal itulah, manusia dan korporasi tidak melakukan tindak pidana. Perumusan ancaman sanksi pidana denda tidak dirumuskan secara eksplisit jumlah denda yang wajib dibayar oleh korporasi, tapi cukup dengan mengkalilipatkan jumlah tersebut dise-suaikan dengan keuntungan yang diperoleh korporasi dan biaya penegakan hu-kum (Euston Quah dan William Neilson, 1993: 1237-1238). 
Bilamana korporasi memper-oleh keuntungan sebesar Rp. 100.000.000.000, 00 maka denda yang dijatuhkan minimal Rp. 200.000.000.000, 00 dan maksimal Rp. 400.000.000.000,00.

Dalam kaitan dengan pelanggaran HAM yang berat oleh korporasi, penjatuhan sanksi pidana denda harus lebih berat dari seriusitas tindak pidana yang dilakukan. Karena hanya dengan cara inilah, korporasi akan berpikir dua kali untuk melakukan pelanggaran HAM yang berat. Namun demikian, jika sanksi pidana tidak mampu di-bayar oleh korporasi, maka sanksi lain yang dapat dijatuhkan adalah dengan meram-pas seluruh aset yang di-miliki oleh korporasi. Selain perampasan aset, sanksi lain yang dapat dijatuhkan adalah dengan mewajibakan korporasi memperbaiki semua akibat dari pelanggaran HAM yang berat yang dilakukan bila berkaitan dengan pen-cemaran lingkungan hidup. Pemberian resti-tusi adalah untuk meringankan beban korban atau keluarganya seandainya korban mening-gal dunia.

Contoh kasus pelanggaran HAM yang dilakukan korporasi salah satunya terjadi di tahun 2003 yaitu kasus majalah TEMPO edisi 9 Maret 2003 yang kemudian pa-da tanggal 16 September 2004 Pengadilan Negeri Jakarta Pusat memutuskan bahwa pemimpin redaksi majalah TEMPO Bambang Harymurti telah melanggar KUHP deng-an dakwaan pencemaran nama baik yang mengungkapkan dugaan keterlibatan Tommy Winata bos grup Artha Graha pada kebakaran pasar Tanah Abang. Pemimpin redaksi majalah TEMPO kala itu divonis 1 tahun penjara (andreasharsono.net, 09 Oktober 2004).

Pada kasus tersebut, dalam putusan hakim hanya menerapkan unsur pidananya saja mengacu pada KUHP tanpa memperhatikan UU No. 40 Tahun 1999 tentang Pers yang secara tegas telah mengatur pertanggungjawaban pidana pada korporasi melalui pasal 18 ayat (2) juncto pasal 12 UU No. 40 Tahun 1999 beserta penjelasannya yang berdasarkan doktrin Respondeat Superior dan Vacarious Liability, maka ten-tulah hakim telah menge-sampingkan asas lex specialis derograt lex generalis.

Jika kita menganalisis pada kasus tersebut diatas, putusan hakim Pengadilan Negeri Jakarta Pusat atas kasus tersebut diatas adalah tidak tepat, karena di dalam ketentuan UU No. 40 Tahun 1999 telah mengatur bahwa pers berbentuk badan hukum sebagai subyek hukum, sedangkan dalam KUHP dan UU No. 1 Tahun 1946 hanya mengenal manusia sebagai subyek hukum, hal ini didasarkan pada pasal 59 KUHP yaitu badan-badan hukum tidak bisa melakukan tindak pidana.

\section{Penutup}

Berdasarkan pembahasan di atas, maka ditarik beberrapa kesimpulan dalam penelitian tentang pertanggungjawaban korporasi dalam pelanggaran HAM di Indonesia (NKRI) adalah sebagai berikut:

1. Ada empat alasan perlunya korporasi dipertanggungjawabkan secara pidana dalam pelanggaran HAM yang berat, yaitu; negara-negara tidak ber-sedia atau tidak memiliki kekuatan untuk menjatuhkan sanksi pidana ke-pada korporasi disebabkan adanya rasa takut negara tersebut 
akan me-nanggung konsekuensi ekonomi yang bersifat negatif; kejahatan kor-porasi di bidang bisnis dan ling-kungan hidup menimbulkan efek negatif yang berkepanjangan dan luar biasa; korporasi seringkali memelihara bu-daya kerja yang mengarah pada terjadinya pelanggaran HAM yang berat; dan seringkali korporasi terlibat langsung dalam pelanggaran HAM yang berat yang serius dan sistemasik.

2. Bila korporasi dipertanggungjawabkan dalam pelanggaran HAM di Indonesia, maka delik penyertaan dalam Pasal 55 KUHP seharusnya direkonstruksi, karena tidak cocok untuk korporasi. Sedangkan yang dipertanggungjawabkan secara pidana haruslah korporasi sendiri, bukan pengurusnya. Adapun bentuk-bentuk sanksi pidana yang dapat dijatuhkan kepada korporasi meliputi pidana denda, perampasan aset korporasi, kewajiban korporasi untuk memulihkan akibat tindak pidana, dan pemberian restitusi kepada korban atau keluarganya. Khusus mengenai formulasi pidana denda, seyogyanya mengikuti prinsip-prinsip dasar dalama nalisis ekonomi atas hukum pidana (economic analysis of criminal law).

\section{DAFTAR PUSTAKA}

\section{BUKU DAN JURNAL}

Ali, Mahrus (2008). Kejahatan Korporasi. Yogyakarta: Arti Bumi Intaran.

Bookman, Zachary (2008). Convergences and Omissions in Reporting Corporate and White Collar Crime. DePaul Business \& Commercial Law Journal.

Clapham, Andrew (2008). Extending International Criminal Law beyond the Individual to Corporations and Armed Opposition Groups. Journal of International Criminal Justice.

Clarkson, C.M.V. (1998). Understanding Criminal Law (Second Edition). London: Sweet \& Maxwell.

Clough, Jonathan (2008). Punishing the Parent: Corporate Criminal Complicity in Human Rights Abuses. Brooklyn Journal of International Law.

Colvin, Eric (1995). Corporate Personality and Criminal Liability. Criminal Law Forum.

Cory Wanless, W. (2009). Corporate Liability for International Crimes under Canada'sCrimes against Humanity and War Crimes Act. Journal of International Criminal Justice.

Friedman, Lawrence (2000). In Defence of Corporate Crimial Liability. Harvard Journal of Law and Public Policy. 
G.A. Tzeutschler, Gregory (1999). Corporate Violator: the Alien Tort Liability of Transnational Corporations for Human Rights Abuses Abroad. Columbia Human Rights Law Review.

Hadjon, Philipus (2007). Perlindungan Hukum Bagi Rakyat di Indonesia. Bandung: Peradaban.

H. Bucy, Pamela (2007). Trends in Corporate Criminal Prosecutions. American Criminal Law Review.

Hanafi, 1997, Strict Liability dan Vicarious Liability dalam Hukum Pidana, Lembaga Penelitian, Universitas Islam Indonesia, Yogyakarta.

Hatrik, Hamzah (1996). Asas Pertanggunggjawaban Korporasi Dalam Hukum Pidana (Strick Liability dan Vicarious Liability). Jakarta: PT Raja Grafindo Persada.

Heaton, Russel (2006). Criminal Law Textbook. London: Oxford University Press.

Henry J. Steiner, Cf. (2009). Organizational Irrationality and Corporate Human Rights Violations. Harvard Law Review.

Hill, Jennifer (2003). Corporate Criminal Liability In Australia: an Evolving Corporate Governance Technique? Journal of Business Law.

I. Blumberg, Phillip (2002). Asserting Human Rights against Multinational Corporations under United States Law: Conceptual and Procedural Problems. American Journal of Comparative Law.

Khanna, V.S. (2000). Corporate Liability Standards: When Should Corporation Be Criminality Liabel? American Criminal Law Review.

Kyriakakis, Joanna (2007). Australian Prosecution of Corporations for International Crimes. Journal of International Criminal Justice.

M. Khan, Dan (2004). Social Influence, Social Meaning, and Deterrence. Virginia Law Review, Vol. 1997.

Priyanto, Dwidja (2004). Kebijakan Legislatif tentang Sistem Pertanggungjawaban Korporasi di Indonesia. Bandung: CV. Utomo.

Mahmud Marzuki, Peter (2006). Penelitian Hukum. Jakarta: Prenada Media.

Orland, Leonard (2006). The Transformation of Corporate Criminal Law. Brooklyn Journal of Corporate, Finansial \& Commercial Law.

Quah, Euston dan Neilson, William (1993). Law and Economics Development: Cases and Materials from Southeast Asia (First Edition). Singapore: Longman Singapore Publishers.

Reksodiputro, Mardjono (1989). Pertanggungjawaban Pidana Korporasi Dalam Tindak Pidana Korporasi. Makalah disampaikan pada Seminar Nasional Kejahatan Korporasi. FH UNDIP, Semarang, 23-24 Novemser.

Soepadi (2010). Kejahatan Koorporasi. Surabaya: Fakultas Hukum Universitas Hang Tuah.

Sutan, Remy Sjahdeini (2006). Pertanggung Jawaban Pidana Korporasi. Jakarta: Grafiti Pers.

Szott Moohr, Geraldine (2007). On The Prospects Of Deterring Corporate Crime. Journal of Business \& Technology Law. 